\title{
FURTHER STUDIES WITH THE SALT TOLERANCE TEST IN NORMAL INDIVIDUALS AND IN PATIENTS WITH ADRENAL CORTICAL HYPERFUNCTION
}

\author{
By L. J. SOFFER, J. L. GABRILOVE, AND M. D. JACOBS \\ (From the Endocrine Section of the Medical Services and the Chemical Laboratories of \\ The Mount Sinai Hospital, New York City)
}

(Received for publication November 26, 1948)

In a previous paper (1) we reported on the utilization of intravenously injected salt before and after the injection of desoxycorticosterone acetate in normal individuals and in patients with Cushing's syndrome. It was pointed out that the injection of this steroid in normal individuals resulted in a decrease in the urinary excretion of sodium and chloride ions as compared to the control values. This is the expected and orthodox effect. On the other hand, the injection of this compound in patients with Cushing's syndrome under the circumstances of our test resulted in an increase in the urinary excretion of sodium and chloride.

Since the publication of the original paper several reports have appeared describing a similar phenomenon occurring under a variety of conditions. Reifenstein (2) has noted a paradoxical salt loss in patients with Cushing's syndrome treated with testosterone. Kriss and Futcher (3) have observed that in two of three patients with Cushing's syndrome, the rate of urinary excretion of sodium, chloride, and water following the rapid intravenous administration of 400 c.c. of $5 \%$ saline exceeded that observed in similarly treated control subjects. In the patients with Cushing's syndrome the increased excretion of the ions and water was accompanied by a reduction in renal tubular reabsorption of these substances, as compared to the controls. In addition, these authors report the instances of two obese females with arterial hypertension in whom the salt tolerance test, employing our technique, was positive at the time of menstruation and negative in the same patients during the intermenstrual period. They suggest that during the menstrual cycle there is a temporary preponderance of adrenocortical influence. In one patient with Cushing's syndrome the salt tolerance test resulted in a normal salt retaining response, despite the fact that the patient exhibited salt diuresis during the clearance study performed five days previously. More recently, Forsham and his coworkers (4) confirmed the paradoxical salt loss following the injection of desoxycorticosterone acetate in patients with Cushing's syndrome. They suggested that the mechanism of this phenomenon was perhaps dependent upon a competitive renal inhibition of desoxycorticosterone as against some other non-salt retaining adrenal cortical fractions.

The mechanism of this paradoxical effect is obscure. We have speculated that it is at least theoretically possible that in some patients with adrenal cortical hyperfunction excessive amounts of saltretaining fractions, manufactured by the increased activity of the adrenal cortex or injected from an exogenous source, are converted into substances lacking salt-retaining effects. The basic structural similarity between those adrenal cortical steroids exercising a salt retaining effect and those lacking it would suggest that the conversion of one into another is perhaps chemically feasible.

\section{METHOD}

The method of study employed is that described previously (1). "All tests were conducted according to the following standard routine: The patients were permitted no food throughout the period of observation and no fluid after 7 P.M. the night before. At 6 A.M. on the morning of the studies the patient was asked to void and the urine was discarded. He was then given 500 c.c. of water to drink at one time, and all of the urine voided was collected over a three-hour period to 9 A.M., carefully labeled and set aside. At 9 A.M., 200 c.c. of $5 \%$ saline (10 grams of salt) was injected intravenously and the urine voided during the next three hours, to $12 \mathrm{M}$., was similarly collected and labeled. Two days later the same procedure was repeated, but, in addition, the patient received $10 \mathrm{mgm}$. of desoxycorticosterone acetate intramuscularly the previous evening at 10 P.M. The urine volume of each period was carefully measured and sodium and chloride determinations were made on each specimen. Sodium was determined according to the method 
of Butler and Tuthill (5), and chlorides according to the method of Harvey (6). The total urinary sodium and chloride ions excreted during the 6 A.M. to 9 A.M. period were subtracted from those excreted between 9 A.M. and 12 M. (period after the intravenous injection). The difference represents the excess over the basal excretion of these ions. This figure in milliequivalents, divided by 171 (i.e., milliequivalents in 10 grams of sodium chloride) yields the fraction of the injected ions excreted $\left(\mathrm{Na}_{\mathrm{e}}\right.$ and $\left.\mathrm{Cl}_{\mathrm{c}}\right)$. The comparison of the results obtained during the control period and that after the injection of desoxycorticosterone acetate shows the percentage of increased retention resulting from the use of the hormone."
Twenty-two normal controls and ten patients with Cushing's syndrome were studied in the present series. The diagnosis of Cushing's syndrome in every instance of this group was established by the presence of a classical clinical picture plus the demonstration, by perirenal insufflation or surgical exploration or both, of an adrenal tumor or bilateral adrenal enlargement. Patients with Cushing's syndrome need manifest no overt gross or histological adrenal cortical abnormalities. For purposes of clarity and definition, however, we have limited our present study to those patients who manifested the usual typical clinical picture and anatomical evidence of adrenal disease. Finally, there are probably many abortive forms of either transient or permanent adrenal cortical hyper-

TABLE I

\begin{tabular}{|c|c|c|c|c|c|c|c|c|c|c|c|c|c|}
\hline \multirow{3}{*}{ Subjects } & \multicolumn{4}{|c|}{ Control } & \multicolumn{4}{|c|}{$\begin{array}{l}\text { After injection of } 10 \mathrm{mgm} \text {. of } \\
\text { desoxycorticosterone acetate }\end{array}$} & \multicolumn{4}{|c|}{ Excretion } & \multirow{3}{*}{$\begin{array}{l}\text { Serum } \\
\text { sodium }\end{array}$} \\
\hline & \multicolumn{2}{|c|}{ Urine volume } & \multirow{2}{*}{$\begin{array}{c}\text { Injected } \\
\mathbf{N a} \text { ex } \\
\text { creted } \\
\mathrm{Na}_{0}\end{array}$} & \multirow{2}{*}{$\begin{array}{l}\text { Injected } \\
\text { Cl ex } \\
\text { creted } \\
\mathrm{Cl}_{0}\end{array}$} & \multicolumn{2}{|c|}{ Urine volume } & \multirow{2}{*}{$\mid \begin{array}{l}\text { Injected } \\
\mathbf{N a} \text { ex- } \\
\text { creted } \\
\text { Nad } \\
\text { Nad }\end{array}$} & \multirow{2}{*}{$\mid \begin{array}{c}\text { Injected } \\
\text { Cl ex } \\
\text { creted } \\
\mathrm{Cl}_{d}\end{array}$} & \multicolumn{2}{|c|}{ Decrease } & \multicolumn{2}{|c|}{ Increase } & \\
\hline & {$\left[\begin{array}{ll}6 & \text { to } \\
\text { A. } & \text { M. } \\
\text {. }\end{array}\right.$} & \begin{tabular}{|l|}
9 to 12 \\
A. M.
\end{tabular} & & & $\left|\begin{array}{ll}6 & \text { to } \\
\text { A. } & 9 \\
\text {. }\end{array}\right|$ & $\begin{array}{l}9 \text { to } 12 \\
\text { A. M. }\end{array}$ & & & $100 \frac{\left(\mathrm{Na}_{\mathrm{c}}-\mathrm{Nad}\right)}{N a_{c}}$ & $100 \frac{\left(\mathrm{Cl}_{\mathrm{c}}-\mathrm{Cl}_{\mathrm{d}}\right)}{\mathrm{Cl}_{\mathrm{c}}}$ & $100 \frac{\left(\mathrm{Nad}_{\mathrm{d}}-\mathrm{Na}_{0}\right)}{\mathrm{Na}_{0}}$ & $100 \frac{\left(\mathrm{Cl}_{\mathrm{d}}-\mathrm{Cl}_{\mathrm{o}}\right)}{\mathrm{Cl}_{\mathrm{o}}}$ & \\
\hline $\begin{array}{l}\text { Normals } \\
\text { I. M. } \\
\text { W. K. } \\
\text { M. W. } \\
\text { J. M. } \\
\text { R. B. } \\
\text { W. C. } \\
\text { B. A. } \\
\text { A. R. } \\
\text { V. V. } \\
\text { F. K. } \\
\text { C. L. } \\
\text { F. B. } \\
\text { T. D. } \\
\text { S. W. } \\
\text { H. L. } \\
\text { I. P. } \\
\text { E. S. } \\
\text { P. K. } \\
\text { A. D. } \\
\text { N. W. } \\
\text { A. L. } \\
\text { P. P. }\end{array}$ & \begin{tabular}{|c|}
$c . c$. \\
395 \\
260 \\
58 \\
755 \\
133 \\
485 \\
90 \\
420 \\
430 \\
330 \\
260 \\
180 \\
390 \\
508 \\
378 \\
110 \\
124 \\
105 \\
650 \\
300 \\
200 \\
698
\end{tabular} & $\begin{array}{l}c . c . \\
232 \\
950 \\
128 \\
170 \\
168 \\
360 \\
102 \\
415 \\
450 \\
375 \\
370 \\
100 \\
472 \\
352 \\
560 \\
170 \\
235 \\
170 \\
290 \\
155 \\
187 \\
323\end{array}$ & \begin{tabular}{r}
\multicolumn{1}{c}{$\%$} \\
10.9 \\
19.1 \\
8.9 \\
6.7 \\
5.1 \\
12.1 \\
1.5 \\
19.1 \\
19.4 \\
30.5 \\
20.4 \\
1.2 \\
39.1 \\
11.7 \\
34.8 \\
8.2 \\
17.3 \\
12.6 \\
21.5 \\
5.6 \\
15.6 \\
24.3
\end{tabular} & $\begin{array}{c}\% \\
11.8 \\
18.4 \\
9.5 \\
7.4 \\
6.2 \\
12.2 \\
2.9 \\
15.6 \\
23.9 \\
34.2 \\
24.0 \\
2.3 \\
42.9 \\
14.6 \\
30.8 \\
10.2 \\
17.7 \\
12.8 \\
28.7 \\
5.6 \\
18.5 \\
16.7\end{array}$ & \begin{tabular}{|r|}
$c . c$. \\
405 \\
245 \\
78 \\
560 \\
140 \\
495 \\
72 \\
558 \\
395 \\
260 \\
340 \\
253 \\
32 \\
720 \\
562 \\
55 \\
230 \\
120 \\
465 \\
200 \\
250 \\
940
\end{tabular} & \begin{tabular}{|r|}
$c . c$. \\
182 \\
770 \\
38 \\
283 \\
220 \\
40 \\
132 \\
352 \\
140 \\
260 \\
180 \\
134 \\
84 \\
218 \\
218 \\
105 \\
183 \\
105 \\
170 \\
118 \\
44 \\
410
\end{tabular} & \begin{tabular}{|r|}
$\%$ \\
6.7 \\
11.8 \\
0.4 \\
8.6 \\
6.4 \\
-14.5 \\
6.3 \\
15.7 \\
0.9 \\
27.2 \\
1.5 \\
1.1 \\
6.0 \\
-0.1 \\
9.6 \\
6.5 \\
7.3 \\
6.4 \\
11.9 \\
1.1 \\
-0.7 \\
8.8
\end{tabular} & \begin{tabular}{|r|}
$\%$ \\
8.0 \\
13.5 \\
0.4 \\
5.4 \\
5.3 \\
-14.5 \\
9.3 \\
16.7 \\
0.5 \\
31.7 \\
0.7 \\
2.3 \\
8.4 \\
-3.9 \\
12.8 \\
8.6 \\
4.7 \\
4.5 \\
16.7 \\
0.1 \\
-1.8 \\
9.1
\end{tabular} & $\begin{array}{c}\% \\
38.5 \\
38.3 \\
95 \\
\\
220 \\
17.8 \\
95 \\
10.8 \\
93 \\
8.4 \\
85 \\
105 \\
73 \\
20.7 \\
59 \\
49 \\
43.5 \\
80 \\
104 \\
66.5\end{array}$ & $\begin{array}{c}98 \\
10.2 \\
97 \\
0 \\
76 \\
126 \\
58 \\
15.4 \\
74 \\
64 \\
42 \\
98 \\
110 \\
45.5\end{array}$ & $\begin{array}{c}28.5 \\
13.8 \\
188\end{array}$ & $\begin{array}{l}220 \\
7.3\end{array}$ & $m . e q / l$ \\
\hline $\begin{array}{l}\text { Cushing's } \\
\text { syndrome } \\
\text { R. S. (1) } \\
\text { R.S. (2) } \\
\text { R. K. } \\
\text { D. F. } \\
\text { H. P. } \\
\text { A. L. } \\
\text { F.P. } \\
\text { T.S. } \\
\text { A. B. } \\
\text { S. G. } \\
\text { J.S. } \\
\text { A.P. } \\
\text { E.S. } \\
\text { E. G. } \\
\text { J. R. } \\
\text { After radio- } \\
\text { therapy } \\
\text { J. R. } \\
\text { S. S. }\end{array}$ & $\begin{array}{l}490 \\
355 \\
840 \\
530 \\
510 \\
385 \\
390 \\
255 \\
370 \\
600 \\
342 \\
378 \\
245 \\
650 \\
168\end{array}$ & $\begin{array}{l}560 \\
650 \\
480 \\
400 \\
295 \\
365 \\
307 \\
190 \\
380 \\
350 \\
130 \\
336 \\
190 \\
250 \\
534\end{array}$ & $\begin{array}{r}19.8 \\
33.3 \\
24.5 \\
4.4 \\
22.0 \\
38.0 \\
14.6 \\
10.8 \\
14.6 \\
8.2 \\
5.9 \\
8.9 \\
26.7 \\
11.8 \\
37.7\end{array}$ & $\begin{array}{r}20.5 \\
30.8 \\
28.1 \\
5.3 \\
19.5 \\
39.5 \\
19.1 \\
14.8 \\
10.1 \\
8.7 \\
5.9 \\
9.1 \\
32.0 \\
12.2 \\
35.4\end{array}$ & \begin{tabular}{|r|}
590 \\
475 \\
1060 \\
305 \\
644 \\
375 \\
277 \\
274 \\
685 \\
470 \\
315 \\
380 \\
297 \\
418 \\
115
\end{tabular} & \begin{tabular}{|r|}
585 \\
535 \\
620 \\
190 \\
400 \\
410 \\
392 \\
365 \\
310 \\
1000 \\
124 \\
418 \\
950 \\
238 \\
745 \\
\end{tabular} & $\begin{array}{r}19.0 \\
16.0 \\
26.3 \\
11.8 \\
41.6 \\
44.7 \\
28.6 \\
39.6 \\
-1.9 \\
44.9 \\
7.8 \\
19.8 \\
70.3 \\
17.3 \\
55.3\end{array}$ & $\begin{array}{r}16.7 \\
15.6 \\
27.3 \\
2.7 \\
43.4 \\
44.8 \\
34.5 \\
36.1 \\
-0.5 \\
43.1 \\
9.1 \\
19.5 \\
59.8 \\
19.0 \\
56.4\end{array}$ & $\begin{array}{l}4.1 \\
52 \\
59\end{array}$ & $\begin{array}{r}18.6 \\
49.5 \\
4.4 \\
49.5\end{array}$ & $\begin{array}{c}7.3 \\
89 \\
17.6 \\
96 \\
280.7 \\
448 \\
32.2 \\
122.4 \\
163.2 \\
46.6 \\
74\end{array}$ & $\begin{array}{c}122 \\
13.4 \\
82 \\
143.8 \\
407 \\
54.2 \\
114.2 \\
87 \\
55.7 \\
60\end{array}$ & $\begin{array}{l}148.4 \\
151 \\
158.2 \\
156.3 \\
141.5 \\
141 \\
137.1 \\
140.1 \\
141.3 \\
142.2\end{array}$ \\
\hline
\end{tabular}


function in which the clinical picture is ill defined, more subtle, and less complete. The response of such patients to the salt tolerance test will await further study.

\section{RESULTS}

In the table are presented the results obtained in the normal individuals and in the 15 patients with Cushing's syndrome. Five of these latter patients were discussed in our previous report (1). In one of the present control series there occurred a diuresis of chloride and sodium following the administration of desoxycorticosterone acetate. In three others there was a minimal diuresis of one or the other of these two electrolytes, but a retention of the other electrolyte.

In ten of the 15 patients with Cushing's syndrome there occurred a diuresis of sodium and chloride following the administration of desoxycorticosterone acetate under the conditions of our test. Five patients failed to show the characteristic response. Of this group of five individuals, one showed a minimal diuresis of sodium but a considerable retention of chloride. Two of the remaining four patients had received intensive $\mathrm{X}$-ray therapy to the hypophysis prior to the performance of the test. In one of these two patients the salt tolerance test was performed both before and after X-ray therapy to the pituitary. Before irradiation there occurred a marked diuresis of sodium and chloride following the administration of the compound, while the repetition of the test after conclusion of X-ray therapy resulted in a retention of sodium and a reduction in the chloride diuresis.

Serum sodium determinations were made in nine of the patients with Cushing's syndrome. Three of this group showed a considerable elevation of the serum sodium, while in the remaining six instances the blood electrolyte values were well within the normal range. One of the latter group and all three of the former showed a retention of sodium or chloride, or both, following the injection of the desoxycorticosterone acetate.

\section{SUMMARY}

1. The salt tolerance test was performed on 22 normal individuals and on 15 patients with adrenal cortical hyperfunction.

2. In one of the control series there occurred a diuresis of sodium and chloride following the administration of desoxycorticosterone acetate under the conditions of our test. In three others there was a minimal diuresis of one or the other of these two electrolytes, but a retention of the other electrolyte.

3. In ten of the 15 patients with adrenal cortical hyperfunction there occurred a diuresis of sodium and chloride following the administration of the hormone.

4. Two of the five patients who failed to show the characteristic response had received intensive $\mathrm{X}$-ray therapy to the pituitary prior to the performance of the test. In one of these patients the test was performed both before and after X-ray treatment. Prior to X-ray therapy the administration of desoxycorticosterone acetate resulted in a diuresis of sodium and chloride, while after treatment there occurred a retention of sodium and a reduction in the degree of chloride diuresis.

5. Blood sodium determinations were made in nine patients with adrenal cortical hyperfunction. In three there occurred a considerable elevation of this electrolyte, while in the remaining six instances the serum sodium was well within the normal range.

6. All three of the former group and one of the latter showed a retention of sodium or chloride or both.

\section{BIBLIOGRAPHY}

1. Soffer, L. J., Lesnick, G., Sorkin, S. Z., Sobotka, H. H., and Jacobs, M., The utilization of intravenously injected salt in normals and in patients with Cushing's syndrome before and after administration of desoxycorticosterone acetate. J. Clin. Invest., 1944, 23, 51.

2. Reifenstein, E. C., Jr., Bone and wound healing. $\mathrm{Tr}$. Fifth Conference on Metabolic Aspects of Convalescence, Josiah Macy Jr. Foundation, 1943, p. 83.

3. Kriss, J. P., and Futcher, P. H., Renal excretion and tubular reabsorption of salt in Cushing's syndrome after intravenous administration of hypertonic sodium chloride. J. Clin. Endocrinol., 1949, 9, 13.

4. Forsham, P. H., Flink, E., Emerson, K., Jr., and Thorn, G. W., Metabolic studies on Cushing's syndrome. J. Clin. Invest., 1949, 28, 781.

5. Butler, A. M., and Tuthill, E., An application of the uranyl zinc acetate method for determination of sodium in biological material. J. Biol. Chem., 1931, 93, 171.

6. Harvey, S. C., The quantitative determination of the chlorides in the urine. Arch. Int. Med., 1910, 6, 12. 